\title{
Competitive Signaling Between TrkA and p75 Nerve Growth Factor Receptors Determines Cell Survival
}

\author{
Sung Ok Yoon,, ${ }^{1}$ Patrizia Casaccia-Bonnefil, ${ }^{2}$ Bruce Carter, ${ }^{3}$ and Moses V. Chao ${ }^{2}$ \\ ${ }^{1}$ Department of Biological Sciences, Columbia University, New York, New York 10027, 25kirball Institute, New York \\ University Medical Center, New York, New York 10016, and ${ }^{3}$ Department of Biochemistry, Center for Molecular \\ Neuroscience, Vanderbilt University Medical School, Nashville, Tennessee 37232
}

In addition to its role as a survival factor, nerve growth factor (NGF) has been implicated in initiating apoptosis in restricted cell types both during development and after terminal cell differentiation. NGF binds to the TrkA tyrosine kinase and the p75 neurotrophin receptor, a member of the tumor necrosis factor cytokine family. To understand the mechanisms underlying survival versus death decisions, the TrkA receptor was introduced into oligodendrocyte cell cultures that undergo apoptosis in a p75-dependent manner. Here we report that activation of the TrkA NGF receptor in oligodendrocytes negates cell death by the p75 receptor. TrkA-mediated rescue from apoptosis correlated with mitogen-activated protein kinase ac- tivation. Concurrently, activation of TrkA in oligodendrocytes resulted in suppression of $c$-jun kinase activity initiated by $p 75$, whereas induction of $\mathrm{NF} \kappa \mathrm{B}$ activity by $\mathrm{p} 75$ was unaffected. These results indicate that TrkA-mediated rescue involves not only activation of survival signals but also simultaneous suppression of a death signal by $\mathrm{p} 75$. The selective interplay between tyrosine kinase and cytokine receptors provides a novel mechanism that achieves alternative cellular responses by merging signals from different ligand-receptor systems.

Key words: apoptosis; neurotrophins; receptor crosstalk; protein kinase; oligodendrocyte; nerve growth factor
Control of cell survival and death by the nerve growth factor (NGF) family of neurotrophin factors is mediated by two transmembrane glycoproteins, the trk receptor tyrosine kinase and the p75 neurotrophin receptor (Chao, 1992; Barbacid, 1994). Neuronal cell survival by neurotrophins requires the activation of Trk tyrosine kinases that signals via a ras-dependent pathway leading to activation of the mitogen-activated protein (MAP) kinases (Kaplan and Stephens, 1994; Greene and Kaplan, 1995) and also through other enzymes, such as phosphatidylinositol-3 kinase (Yao and Cooper, 1995). The p75 receptor, a member of the tumor necrosis factor (TNF) cytokine receptor superfamily, activates ceramide production, $\mathrm{NF} \kappa \mathrm{B}$, and c-Jun $\mathrm{N}$-terminal kinase (JNK) (Bothwell, 1996; Casaccia-Bonnefil et al., 1996).

One role for p75 is augmenting TrkA function during cell survival and differentiation. For instance, the expression of p75 in sympathoadrenal cells leads to increased tyrosine phosphorylation of TrkA and enhanced differentiation by NGF (Verdi et al., 1994), and the removal of p75 in trigeminal sensory neurons results in a shift in the NGF dose requirement for optimal survival (Davies et al., 1993; Lee et al., 1994). The positive effects of p75 on cell survival and differentiation may be explained by the binding properties of $\mathrm{p} 75$ and TrkA, in which p75 participates in forming high-affinity binding sites (Hempstead et al., 1991; Mahadeo et al., 1994), which lowers the concentration of NGF required for signal transduction (Barker and Shooter, 1994).

\footnotetext{
Received Dec. 12, 1997; revised Feb. 13, 1998; accepted Feb. 13, 1998.

This work was supported by a grant from the Multiple Sclerosis Society to S.O.Y. and P.C.B. and by National Institutes of Health Grants HD23315 and NS271072 to P.C.B., B.C., and M.V.C. We thank Nicola Neff of Cephalon, Inc. and Kyowa Hakko Kogyo Co., Ltd. for providing CEP-1347 and Rick Dobrowsky and Thomas Franke for advice and help.

Correspondence should be addressed to Moses V. Chao, New York University Medical Center, 540 First Avenue, New York, NY 10016.

Copyright (C) 1998 Society for Neuroscience $0270-6474 / 98 / 183273-09 \$ 05.00 / 0$
}

In addition to facilitating survival and differentiation by TrkA, p75 can act as an inducer of apoptosis in vitro and in vivo (Bredesen and Rabizadeh, 1997; Carter and Lewin, 1997). In embryonic chick retina, p75-expressing neural precursor cells undergo apoptosis in an NGF-dependent manner in the absence of TrkA, suggesting that NGF induces developmentally regulated cell death through p75 (Frade et al., 1996). Among cholinergic neurons in the basal forebrain that normally express both TrkA and p75 in the adult, p75 is implicated in cell death among p75-expressing neurons in the absence of TrkA (Van der Zee et al., 1996; Yeo et al., 1997). Overexpression of the cytoplasmic domain of p75 in transgenic mice resulted in prominent cell death in both peripheral neurons, which normally express $\mathrm{p} 75$, and in central neurons, which do not normally express the receptor (Majdan et al., 1997).

Other in vitro studies also indicate that actions of the $\mathrm{p} 75$ receptor can mediate apoptosis. Expression of p75 in immortalized neuronal cell lines leads to a faster rate of apoptosis after serum deprivation (Rabizadeh et al., 1993). In terminally differentiated primary oligodendrocytes, p75 induces apoptosis in an NGFdependent manner (Casaccia-Bonnefil et al., 1996). This apoptotic response was shown to require NGF binding to the p75 receptor, because the cell death could be reversed by anti-p75 antibodies.

The decision between survival and death among NGFresponsive neurons may be determined by the ratio of p75 to Trk receptors (Davies et al., 1993; Barrett and Bartlett, 1994; Lee et al., 1994). For instance, a decrease in the level of p75 leads to an increase in cell death in embryonic sensory neurons. In postnatal sensory neurons, however, a similar decrease of p75 results in an increase in cell survival (Barrett and Bartlett, 1994). During development, the ratio of p75 to TrkA varies in the periphery (Wyatt and Davies, 1993; Wyatt and Davies, 1995). These results suggest that the ability of p75 to act in a positive or negative 
manner on cell viability may depend on the levels of the two receptors during different stages of neuronal development.

What signaling mechanism is responsible for this dichotomy in NGF action? To address this question, we used the oligodendrocyte as an experimental system. Primary cultures of fully mature oligodendrocytes express a high level of p75 receptor and undergo rapid cell death in response to NGF (Casaccia-Bonnefil et al., 1996). In this study, we investigated how ectopic expression of TrkA affects p75-mediated cell death and what signals are responsible for cell death and survival outcomes. Our results demonstrate that activation of TrkA prevented p75-mediated apoptosis in these oligodendrocytes, and this rescue was accompanied by a selective modulation of p 75 signaling.

\section{MATERIALS AND METHODS}

Isolation of oligodendrocytes. Primary cultures of rat cortical oligodendrocytes were prepared as described previously (McCarthy and de Vellis, 1980; Casaccia-Bonnefil et al., 1996). Sprague Dawley rat pups [postnatal day $1(\mathrm{P} 1)]$ were killed by decapitation, and cortices were dissected from their meninges and dissociated by sequential trituration. Cells were plated into $75 \mathrm{~cm}^{2}$ flasks coated with $0.1 \mathrm{mg} / \mathrm{ml}$ poly-D-lysine in the presence of MEM supplemented with $15 \%$ fetal bovine serum (Life Technologies, Gaithersburg, MD) and $1 \%$ penicillin-streptomycin (NM15 media). The cultures were grown for 8-9 d, with changes of media every $2 \mathrm{~d}$. The flasks were then shaken for $10 \mathrm{~min}$ at $400 \mathrm{rpm}$ and $37^{\circ} \mathrm{C}$, and the supernatants containing microglia were replaced with fresh NM15 media after a wash with $1 \times$ PBS. After a 5-6 hr incubation at $37^{\circ} \mathrm{C}$, the cultures were subjected to an overnight shaking at $250 \mathrm{rpm}$ and $37^{\circ} \mathrm{C}$. The resulting oligodendrocyte precursor cells were further purified from astrocytes by subsequent preplating steps using $10 \mathrm{~cm}$ uncoated Falcon dishes for $1 \mathrm{hr}$. The preplating step was repeated twice. Typically, a yield of $1 \times 10^{7}$ cells was obtained from one litter of rat pups. Greater than $94 \%$ of the cells stained positive for the oligodendrocyte marker O1, and less than $5 \%$ of cells were stained for the astrocytic marker GFAP. The purified oligodendrocyte precursors were plated on poly-D-lysinecoated dishes.

Generation of TrkA retrovirus. The human TrkA cDNA (Martin-Zanca et al., 1989) was cloned into the EcoRI site of pLIA vector (a gift from Dr. Connie Cepko, Harvard Medical School, Boston, MA). Stable lines expressing either the TrkA cDNA or a null vector were obtained by transfecting the E86 packaging line (a gift from Dr. Tony Brown, Cornell Medical School, New York, NY) with an SV2Neo as a selection marker. Positive cell lines were identified by alkaline phosphatase staining and also by immunoprecipitation and Western analyses using anti-Trk antibody 203 . The positive virus was harvested and concentrated by centrifugation at $15,000 \times g$ for $2 \mathrm{hr}$ at $25^{\circ} \mathrm{C}$. The titer of virus ranged from 0.5 to $1 \times 10^{8} \mathrm{pfu} / \mathrm{ml}$ after concentration. The virus was stored in liquid nitrogen.

Retrovirus infection. Retroviral infection was performed on P1 oligodendrocyte precursors maintained in NM15 medium. By bromodeoxyuridine incorporation, $80 \%$ of cultures at this stage were undergoing cell division (data not shown). The infection took place with 0.5-1 $\mathrm{pfu} /$ cell retrovirus in NM15 media in the presence of $10 \mu \mathrm{g} / \mathrm{ml}$ polybrene. After a $2 \mathrm{hr}$ incubation at $37^{\circ} \mathrm{C}$, cultures were refed with fresh NM15 for 5-6 hr. The infected precursors were then allowed to differentiate in oligodendrocyte differentiation media (see below). Infected cultures were maintained in differentiation media for $7 \mathrm{~d}$ with refeeding at every $2 \mathrm{~d}$ by replacing half the media with fresh media. Typically, $60-80 \%$ of oligodendrocytes were infected with the retrovirus, as assessed by alkaline phosphatase staining.

Cell culture. Oligodendrocyte cultures were typically grown for 5-16 hr in NM15 media after preplating and then allowed to grow in oligodendrocyte differentiation media ( $\mathrm{N} 2$ derivative) containing Basal Medium Eagle/F-12 (1:1), $100 \mu \mathrm{g} / \mathrm{ml}$ transferrin, $20 \mu \mathrm{g} / \mathrm{ml}$ putrescine, $12.8 \mathrm{ng} / \mathrm{ml}$ progesterone, $10.4 \mathrm{ng} / \mathrm{ml}$ selenium, $25 \mu \mathrm{g} / \mathrm{ml}$ insulin, $0.8 \mu \mathrm{g} / \mathrm{ml}$ thyroxine, $0.6 \mathrm{gm} / 100 \mathrm{ml}$ glucose, and $6.6 \mathrm{~mm}$ glutamine. For cell death assays, oligodendrocyte cultures were grown for $7 \mathrm{~d}$ and treated with NGF at 100 $\mathrm{ng} / \mathrm{ml}$. For CEP-1347 treatment, cells were pretreated with the appropriate dilutions of the drug for $30 \mathrm{~min}$ before NGF exposure. CEP-1327 was prepared in DMSO and stored at $4^{\circ} \mathrm{C}$ in the dark (Maroney et al., 1997). Surviving cells were scored using calcein AM green fluorescence
(Live/Dead; Molecular Probes, Eugene, OR) according to the manufacturer's instructions.

PCR analysis. Total RNA was isolated from oligodendrocyte cultures grown either in the presence of B104 neuroblastoma conditioned media, FGF, and PDGF or oligodendrocyte differentiation media. The RNA was reverse transcribed into cDNA using random hexamers. The cDNA was subjected to 35 cycles of amplification using the primers $5^{\prime}$ AGGTGTTTCGTCCTTCTTCTC-3' and 5' -TTCGGCCAGGCCTCCGCCTCC $-3^{\prime}$ at $94^{\circ} \mathrm{C}$ for $2 \mathrm{~min}, 62^{\circ} \mathrm{C}$ for $2 \mathrm{~min}$, and $72^{\circ} \mathrm{C}$ for $60 \mathrm{sec}$. PCR products were resolved by a $12 \%$ acrylamide gel.

For measurements of TrkA mRNA by reverse transcription-PCR (RTPCR), RNA was isolated from oligodendrocyte cultures grown according to other published protocols (Cohen et al., 1996). Progenitors were cultured either (1) in the presence of $20 \%$ B104 conditioned medium or (2) in DMEM/F-12 supplemented with $5 \mu \mathrm{g} / \mathrm{ml}$ insulin, $30 \mathrm{~nm}$ selenium, $25 \mu \mathrm{g} / \mathrm{ml}$ transferrin, $20 \mathrm{nM}$ progesterone, $1 \mu \mathrm{g} / \mathrm{ml}$ putrescine, $30 \mathrm{nM}$ triiodothyroxine, and $0.1 \% \mathrm{BSA}$ in the presence of $2 \mathrm{ng} / \mathrm{ml} \mathrm{FGF}$ and 2 $\mathrm{ng} / \mathrm{ml} \mathrm{PDGF}$ for $4 \mathrm{~d}$. After exposure to mitogens, oligodendrocytes were induced to differentiate by removing FGF and PDGF from the same serum-free medium.

Alkaline phosphatase staining. Cells were fixed for $20 \mathrm{~min}$ with $3 \%$ paraformaldehyde in $0.1 \mathrm{M}$ phosphate buffer, $\mathrm{pH}$ 7.2. For alkaline phosphatase enzymatic reaction, fixed cells were first preincubated at room temperature with $1.2 \mathrm{mg} / \mathrm{ml}$ levamisole (L-2,3,5,6-tetrahydro-6phenylimidaz[2,1]thiazole) in $0.1 \mathrm{M}$ Tris, pH 9.5, $0.1 \mathrm{M} \mathrm{NaCl}$, and $50 \mathrm{~mm}$ $\mathrm{MgCl}_{2}$. After a $30 \mathrm{~min}$ incubation, cells were then kept overnight in the dark at room temperature in the same buffer with the addition of 0.1 $\mathrm{mg} / \mathrm{ml} \mathrm{5-bromo-4-chloro-3-indolyl-phosphate} \mathrm{(4-toluidine} \mathrm{salt),} \mathrm{and} 1$ $\mathrm{mg} / \mathrm{ml}$ of nitro blue tetrazolium chloride.

Terminal deoxynucleotidyl tranferase-mediated biotinylated UTP nick end-labeling procedure. Quantitation of apoptotic cells was assessed by counting the terminal deoxynucleotidyl tranferase-mediated biotinylated UTP nick end-labeling (TUNEL)-positive cells among the alkaline phosphatase-positive cells. For TUNEL reaction, alkaline phosphatasestained cells were treated for 2 min with $0.1 \%$ Triton $X-100$ in $0.1 \%$ sodium citrate. After several washes with $1 \times$ PBS, $50 \mu$ l of TUNEL reaction mixture was added to each sample and incubated for $1 \mathrm{hr}$ at $37^{\circ} \mathrm{C}$ in the dark. Apoptotic cells were determined by counting TUNELpositive cells among alkaline phosphatase-positive cells that bore oligodendrocytic morphology at $400 \times$ magnification. In total, 500-600 cells were counted for each treated condition.

p75 staining. For triple staining to detect p75 receptor expression, alkaline phosphatase (AP), and TUNEL reactivity, cells were first processed for the AP enzymatic reaction, as described, and incubated for 1 $\mathrm{hr}$ at room temperature with $10 \%$ rabbit serum in a buffer containing $0.1 \%$ Triton $\mathrm{X}-100$ and $0.1 \mathrm{~m}$ phosphate buffer (PB), $\mathrm{pH} 7.2$, as a blocking step. Incubation with anti-p75 antibody 9651 (Huber and Chao, 1995a) was performed overnight at $4^{\circ} \mathrm{C}$ at a 1:2000 dilution in a buffer containing $5 \%$ goat serum and $0.1 \mathrm{M} \mathrm{PB}$. After the primary incubation, samples were washed several times with $0.1 \mathrm{M} \mathrm{PB}$ and then subjected to TUNEL reaction as described above. Samples were incubated with the secondary antibody, biotinylated anti-rabbit (Vector Laboratories, Burlingame, $\mathrm{CA}$ ), at $1: 100$ in incubation buffer for $1 \mathrm{hr}$ at room temperature and further treated with streptavidin-Cy3 at 1:100 for $30 \mathrm{~min}$.

Immunoprecipitation and Western analysis. Cultured oligodendrocytes were washed once and collected after centrifugation at $5000 \times g$ for 5 $\mathrm{min}$ at $4^{\circ} \mathrm{C}$. The cells were lysed on ice in a buffer containing $1 \% \mathrm{NP}-40$, $20 \mathrm{~mm}$ Tris, pH 8.0, $137 \mathrm{~mm} \mathrm{NaCl}, 0.5 \mathrm{~mm}$ EDTA, $10 \%$ glycerol, $10 \mathrm{~mm}$ $\mathrm{Na}_{2} \mathrm{P}_{2} \mathrm{O}_{7}, 10 \mathrm{~mm} \mathrm{NaF}, 1 \mathrm{mg} / \mathrm{ml}$ aprotinin, $10 \mathrm{mg} / \mathrm{ml}$ leupeptin, $1 \mathrm{~mm}$ vanadate, and $1 \mathrm{~mm}$ PMSF. At lysis, the lysates were spun at 15,000 $\times g$ for $15 \mathrm{~min}$, and the supernatants were collected. For the immunoprecipitation, lysates were incubated for $2 \mathrm{hr}$ with the primary antibodies and for an additional $1 \mathrm{hr}$ with the protein A-Sepharose. The protein A-Sepharose beads were then washed three times in the lysis buffer and once with $50 \mathrm{~mm}$ Tris, $\mathrm{pH}$ 7.5. The samples were boiled for 3-5 min in sample buffer and then subjected to SDS-PAGE. For Western analysis, the proteins were transferred onto nitrocellulose paper and blocked for $2-3 \mathrm{hr}$ at room temperature in a buffer containing $1 \%$ BSA, $20 \mathrm{~mm}$ Tris, $\mathrm{pH} 7.5,137 \mathrm{~mm} \mathrm{NaCl}$, and $0.1 \%$ Tween 20 . Incubation with primary antibodies was performed overnight at $4^{\circ} \mathrm{C}$ in the same buffer as a blocking buffer. For detection, an ECL chemiluminescence system (Amersham, Arlington Heights, IL) was used with HRP-conjugated secondary antibodies (Boehringer Mannheim, Indianapolis, IN). Antibodies used in this study were as follows: 203, anti-trk tyrosine kinase (Hempstead et al., 1992); 4G10, anti-phosphotyrosine (Upstate Biotechnology, 
A)

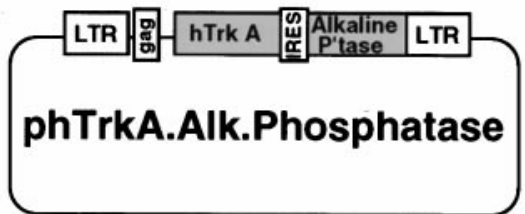

B) PY

203

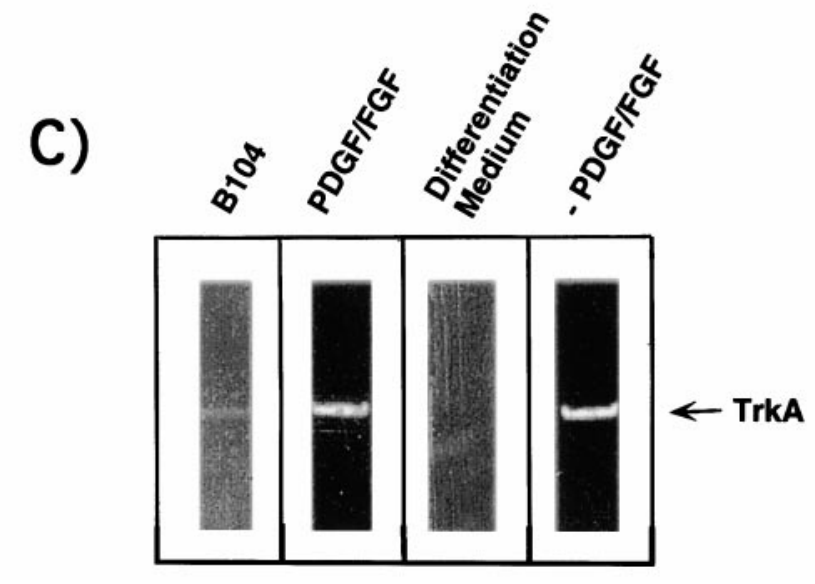

Figure 1. Expression of human TrkA receptors in oligodendrocytes after retroviral infection. $A$, Diagram of the recombinant TrkA retrovirus. The human TrkA cDNA was subcloned upstream of an IRESlinked alkaline phosphatase gene. $B$, Ligand-dependent activation and expression of TrkA in oligodendrocytes. Differentiated oligodendrocytes infected with TrkA (TrkA) or null (Con) retroviruses were either treated or untreated with $100 \mathrm{ng} / \mathrm{ml}$ NGF for $5 \mathrm{~min}$. Tyrosine phosphorylation of TrkA receptors was detected after immunoprecipitation with an anti-Trk (203) antibody and Western blot with anti-phosphotyrosine antibodies $4 \mathrm{G} 10$ and PY20 (PY). The level of receptor expression under each condition was determined by reprobing the same blot with the anti-Trk 203 antibody. $C$, TrkA expression is induced by mitogenic stimuli. The expression of TrkA mRNA was monitored by reverse transcription-PCR using RNA isolated from oligodendrocyte progenitors and mature oligodendrocytes cultured in different conditions. A 129 bp fragment was amplified for rat trkA mRNA. Progenitors were maintained for $4 \mathrm{~d}$ either in DMEM supplemented with $20 \%$ B104 conditioned medium (B104) or with $2 \mathrm{ng} / \mathrm{ml}$ basic FGF and PDGF $(P D G F / F G F)$ before RNA harvesting. Oligodendrocytes were differentiated either from progenitors directly placed in serum-free defined medium (Differentiation Medium) or from progenitors expanded in PDGF and bFGF $(-P D G F / F G F)$. TrkA mRNA is induced by mitogenic stimuli and persists after removal of the growth factors.

Lake Placid, NY); PY20, anti-phosphotyrosine (Transduction Laboratories, Lexington, KY); anti-MAP kinase; and anti-JNK (Santa Cruz Biotechnology, Santa Cruz, CA).

MAP and JNK kinase activity assay. Measurements of MAP kinase activity were performed using myelin basic protein as a substrate, as described previously (Teng et al., 1995). JNK kinase assays were performed with a glutathione $S$-transferase (GST)-c-Jun (1-79) fusion protein as a substrate after immunoprecipitation of the cell lysates with agarose-conjugated anti-JNK antibodies (Westwick et al., 1995). Phosphorylation of myelin basic protein (MBP) and GST-c-Jun was evaluated after gel electrophoresis and autoradiography and quantitated using PhosphorImager analysis.

$N F \kappa B$ assay. Whole-cell extracts were prepared from TrkA virusinfected oligodendrocytes or from control virus-infected cells. Seven days after infection, differentiated oligodendrocytes were gently rinsed twice by replacing half the media with fresh media. NGF was then added at $100 \mathrm{ng} / \mathrm{ml}$ for $1 \mathrm{hr}$ of incubation at $37^{\circ} \mathrm{C}$. The cells were then gently rinsed with ice-cold PBS and harvested by scraping with a $1 \mathrm{ml} / 10 \mathrm{~cm}$ plate of ice-cold PBS, with the addition of $100 \mu \mathrm{M}$ PDTC to block further $\mathrm{NF} \kappa \mathrm{B}$ activation during the harvest procedure. Cells were pelleted at $4^{\circ} \mathrm{C}(730 \times g)$ and lysed in $50 \mu \mathrm{l}$ of a high-salt lysis buffer $(20 \mathrm{mM}$ HEPES, pH 7.9, $0.35 \mathrm{M} \mathrm{NaCl}, 20 \%$ glycerol, $1 \% \mathrm{NP}-40,1 \mathrm{~mm} \mathrm{MgCl}_{2}, 0.5 \mathrm{~mm}$ EDTA, $0.1 \mathrm{~mm}$ EGTA, $1 \mathrm{~mm}$ DTT, and $1 \mathrm{~mm}$ PMSF), and after $10 \mathrm{~min}$ the cell debris was removed by centrifugation at $16,000 \times g$ for $10 \mathrm{~min}$. The whole-cell lysate was then immediately frozen in liquid $\mathrm{N}_{2}$ and stored at $-80^{\circ} \mathrm{C}$.

For the electrophoretic mobility shift assay, the whole-cell lysate was thawed on ice, and equivalent amounts of the whole-cell lysates (7-20 ng of protein) were incubated with $20,000-50,000 \mathrm{cpm}$ of ${ }^{32} \mathrm{P}$-labeled oligonucleotide corresponding to the $\kappa$ light chain enhancer in a final volume of $20 \mu \mathrm{l}$ with binding buffer [ $25 \mathrm{~mm}$ HEPES, $\mathrm{pH} 7.9,5 \%$ glycerin, $70 \mathrm{~mm}$ $\mathrm{KCl}, 0.2 \mathrm{~mm}$ EDTA, $0.27 \%$ NP-40, $4 \%$ Ficoll 400, $1 \mathrm{mg} / \mathrm{ml}$ BSA, 0.1 $\mathrm{mg} / \mathrm{ml}$ poly(dI-dC), $2 \mathrm{~mm}$ DTT, and $0.2 \mathrm{~mm}$ PMSF]. After incubation for $30 \mathrm{~min}$ on ice, the reactions were separated on a nondenaturing
$4 \%$ acrylamide gel, dried, and exposed to film or visualized with a PhosphorImager (Molecular Dynamics, Sunnyvale, CA).

$N F \kappa B$ immunostaining. Oligodendrocytes infected with trkA or control virus were cultured as above for $7 \mathrm{~d}$ in differentiation media in four chamber slides. The cells were gently rinsed by exchanging half the media twice, treated with $100 \mathrm{ng} / \mathrm{ml} \mathrm{NGF}$ or no factor for $1 \mathrm{hr}$ at $37^{\circ} \mathrm{C}$, and then fixed for $2 \mathrm{~min}$ in ice-cold $100 \%$ ethanol followed by $5 \mathrm{~min}$ in $3.7 \%$ formaldehyde. After a PBS rinse, the cells were blocked in 5\% normal goat serum in PBS, rinsed in PBS, and stained with anti-p65 (Boehringer Mannheim) at 1:20 in PBS for $2 \mathrm{hr}$ to overnight. The cells were rinsed with PBS, incubated with biotinylated anti-mouse secondary serum at 1:100, and stained with 1:100 fluorophore/streptavidin-Cy3. The stained cells were visualized with a fluorescent microscope.

\section{RESULTS}

To address the mechanism by which NGF produces a survival or death signal through its receptors, we have used oligodendroglial cells that display high levels of p75 neurotrophin receptor after long-term culture. Oligodendrocyte progenitor cells $\left(\mathrm{A} 2 \mathrm{~B}^{+}{ }^{+} \mathrm{O} 1^{-}\right)$were isolated after shaking mixed glial cultures (McCarthy and de Vellis, 1980) and then allowed to differentiate in oligodendrocyte differentiation media to mature cells expressing myelin-associated glycoprotein (MAG) and MBP.

To evaluate the receptor-mediated events that lead to survival of oligodendrocytes, we introduced the human trkA cDNA in oligodendroglial progenitor cells prepared from postnatal glial cell cultures. A recombinant retrovirus carrying the human TrkA cDNA was used to infect bipolar progenitor cells. A retrovirus containing the expression plasmid alone was used as a control. 


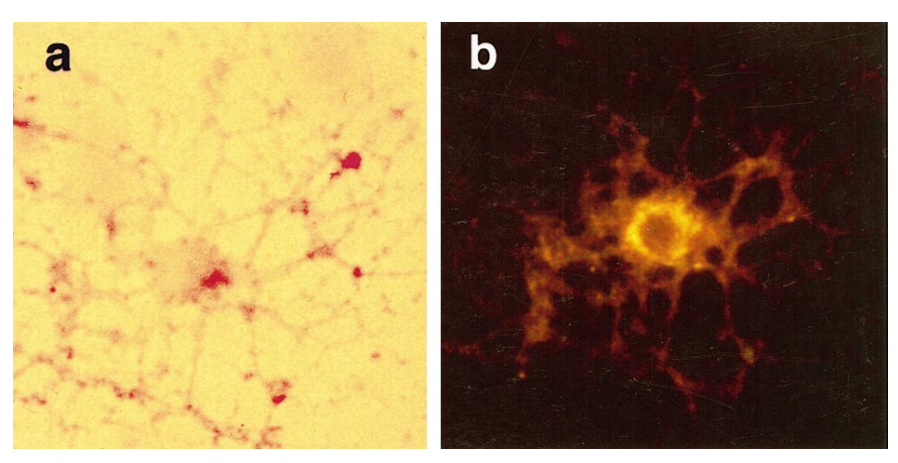

Figure 2. Expression of p75 in oligodendrocytes infected with the trkA retrovirus. Differentiated oligodendrocytes infected with trkA retrovirus were stained for alkaline phosphatase $(a)$ and p 75 receptors $(b)$ using the 9651 anti-p75 polyclonal antibody (Huber and Chao, 1995a). Cultures were allowed to grow in oligodendrocyte differentiation media for $7 \mathrm{~d}$ before staining. Cell shown was TUNEL-negative. Magnification, 400×.

The infected progenitor cells were allowed to differentiate in culture in the absence of mitogens.

The TrkA recombinant and control virus also carried the cDNA for the human alkaline phosphatase (Fig. 1A) under control of the internal ribosome entry site (IRES), allowing for identification of infected cells (Fields-Berry et al., 1992). Expression of the TrkA receptors was monitored by immunoprecipitation and Western blot analysis of lysates from differentiated oligodendrocytes (Fig. 1B). After NGF treatment, activation of TrkA was observed using anti-phosphotyrosine antibodies (Fig. $1 B, P Y$ ).

Expression of endogenous $\operatorname{trk} A$ mRNA was not observed in cultures infected with a null virus and cultured in the absence of mitogens (Fig. 1C). Under these culture conditions, oligodendrocytes continue to express high levels of p75. Expression of TrkA receptors in oligodendroglial cultures, however, has been reported (Althaus et al., 1992; Cohen et al., 1996). Indeed, when we expand oligodendrocyte progenitors with basic FGF (bFGF) and PDGF before differentiation conditions (Raff et al., 1988; McKinnon et al., 1990), TrkA expression could be detected in mature oligodendrocytes by RT-PCR analysis (Fig. 1C). We have chosen growth conditions that do not induce endogenous TrkA expression to rule out potential effects of bFGF and PDGF signaling on cell survival.

\section{Rescue by TrkA}

Oligodendrocyte cultures were established under growth conditions that allowed for the expression of $\mathrm{p} 75$ receptors in the absence of TrkA after $7 \mathrm{~d}$ in differentiation media (Casaccia-Bonnefil et al., 1996). Cultures of oligodendrocytes coexpressing both p75 and TrkA were obtained after retroviral infection of progenitor cells with a bicistronic vector containing the human TrkA and alkaline phosphatase cDNAs. TrkA ${ }^{+}$and $\mathrm{p}^{+} 5^{+}$cells were identified by double staining for alkaline phosphatase and p75 (Fig. 2).

The viability of these oligodendrocyte cultures was assessed by TUNEL staining. Examples of a TUNEL-positive oligodendrocyte infected with the control virus and a TUNEL-negative oligodendrocyte infected with the TrkA virus are shown in Figure 3. After treatment of p $75^{+}$cultures with $100 \mathrm{ng} / \mathrm{ml} \mathrm{NGF}$ for $4 \mathrm{hr}$, the number of TUNEL-positive cells among alkaline phosphatasestained cells increased to $43 \%$ (Fig. 4). In contrast, only $13 \%$ of cells coexpressing p75 and trkA were TUNEL-positive. This level represented a significant reduction in cell death compared with cultures expressing p75 alone and reflected the normal background level of death observed in $7 \mathrm{~d}$ in vitro cultures (Fig. 4). These results indicate that TrkA expression overrides the death-promoting activity of $\mathrm{p} 75$ when the two receptors are expressed together.

The apoptotic effects of NGF on these cultures were dependent on several conditions. Under the serum-free growth conditions used in this study, oligodendrocyte cultures were pushed toward terminal differentiation and became susceptible to cell death. These cultures were not exposed to FGF and PDGF or B104 conditioned media, two common methods for propagating and sustaining oligodendrocytes. Furthermore, the increase in TUNEL-positive cells was only observed after at least 1 week in culture in the absence of growth factors and required NGF binding to p75 receptors (Casaccia-Bonnefil et al., 1996). Hence, the rescue of oligodendrocytes expressing TrkA is a striking reversal of the cell death effects of NGF in this system.

\section{TrkA negates $\mathrm{p} 75$ signaling}

How does TrkA reverse the death-promoting activity by p75? To investigate the signaling mechanism by which TrkA is able to promote cell survival, the activities of MAP kinases (ERK1 and 2) and JNK were assessed. Whereas MAP kinases are induced after TrkA tyrosine kinase autophosphorylation by NGF (Greene and Kaplan, 1995), the stress-activated protein kinase JNK is activated by NGF binding to p75 in differentiated oligodendrocytes (Casaccia-Bonnefil et al., 1996). The JNK pathway plays a role in triggering apoptosis after environmental stresses such as UV irradiation and withdrawal of trophic factors from sympathetic or PC12 cells (Derijard et al., 1994; Ham et al., 1995; Xia et al., 1995; Park et al., 1996; Verheij et al., 1996).

In $\mathrm{p} 75^{+}$cultures infected with the control retrovirus, there was little increase in MAP kinase activity by NGF, as assessed by its ability to phosphorylate myelin basic protein. Hence, p75 did not activate MAP kinase in these cultures. However, NGF binding to p75 led to increased JNK activity in oligodendrocytes, as assessed by an immune kinase assay using a GST-c-Jun fusion protein as a substrate (Fig. 5). In contrast, JNK activity was suppressed in oligodendrocytes expressing both p75 and TrkA receptors, whereas MAP kinase activity was increased twofold to threefold (Fig. 5). Induction of MAP kinases ERK1 and 2 and concomitant suppression of JNK activity suggest that TrkA may modulate the capacity of p75 to give a death signal in these cultures.

To analyze the significance of JNK activity in oligodendrocyte cell death, we tested the effect of a novel inhibitor of the JNK pathway, CEP-1347, also known as KT7515 (Kaneko et al., 1997). CEP-1347 is an alkaloid derivative that increases choline acetyltransferase activity in basal forebrain cultures (Kaneko et al., 1997) and inhibits JNK activity and apoptosis of motor neurons in vitro (Maroney et al., 1997). Treatment of differentiated oligodendrocyte cultures with $1 \mu \mathrm{M}$ CEP-1347 rescued $90 \%$ of the cells from NGF-induced cell death (Fig. 6). This effect was dosedependent and occurred at the same concentration required to obtain suppression of NGF-dependent JNK activation, as assayed by an immune kinase measurement (Fig. 6C). These combined results further indicate that p75-mediated increases in JNK activity play an essential role in the apoptotic response observed in cultured oligodendrocytes.

\section{NF $\boldsymbol{\kappa}$ B activation}

In Schwann cells, NGF binding to p75 leads to the activation of $\mathrm{NF} \kappa \mathrm{B}$ (Carter et al., 1996), a response that is also initiated by many cytokines and TNF family ligands (O'Niell and Kaltschmidt, 1997). Activation of $\mathrm{NF} \kappa \mathrm{B}$ may serve as a protective 

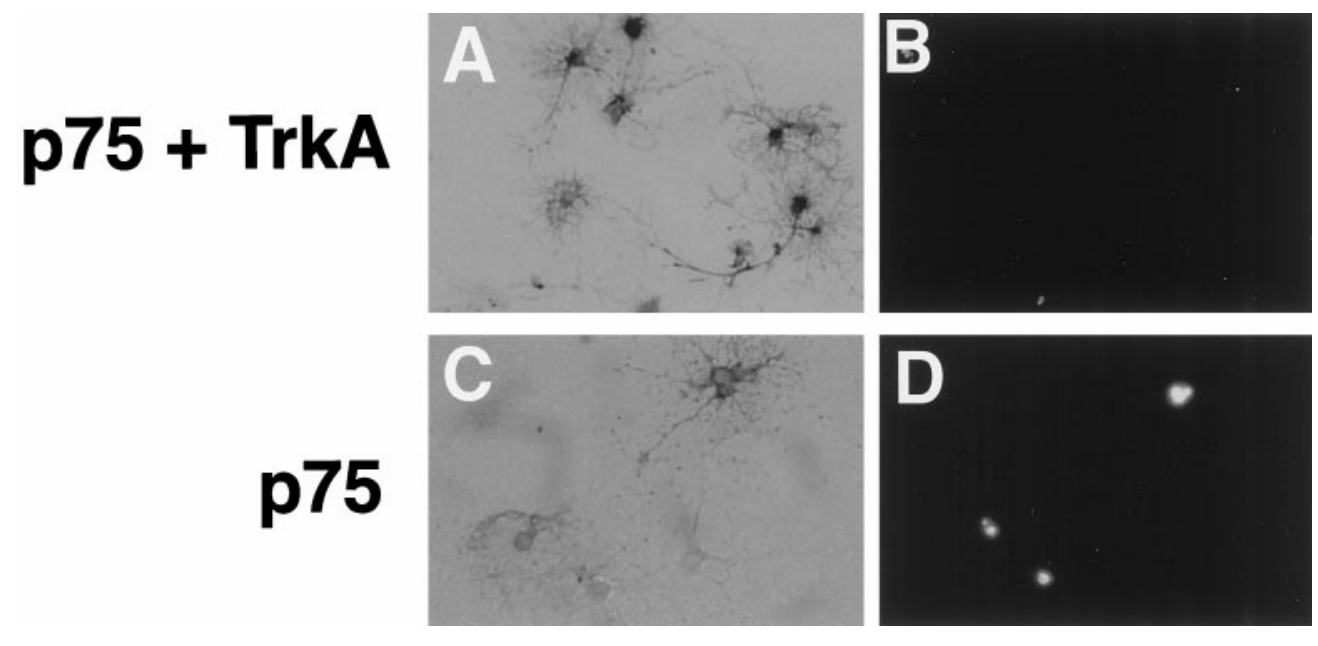

Figure 3. Oligodendrocytes infected with TrkA or null virus. Cells infected with either the TrkA virus $(A, B)$ or control null virus $(C, D)$ were identified by staining for alkaline phosphatase $(A$, $C)$. $B, D$, TUNEL staining of the same field of cells. Magnification, 200×.
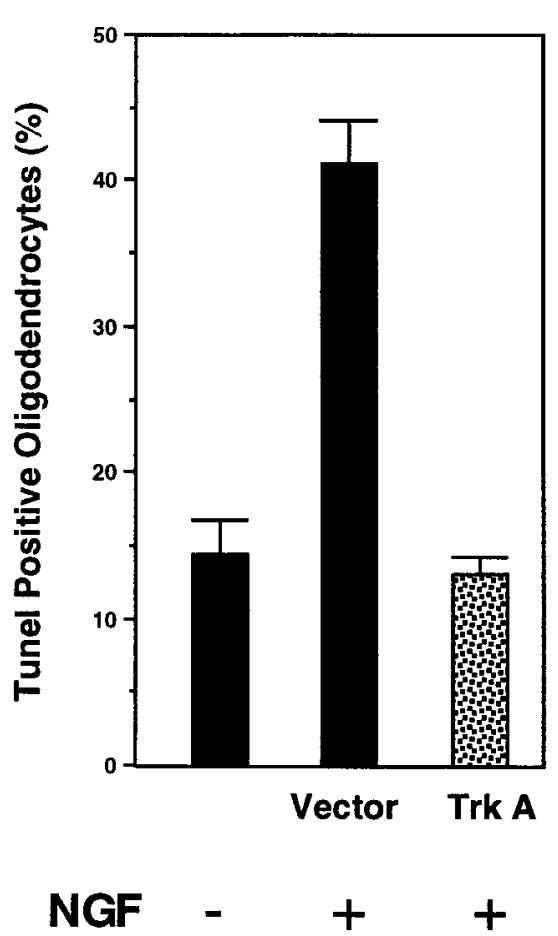

Figure 4. TrkA prevents p75-mediated apoptosis. Quantification of TrkA-mediated rescue was performed after the TUNEL assay, as described in Materials and Methods. The number of TUNEL-positive cells in similar untreated cultures is indicated. In total, 500-600 cells were counted from four separate experiments.

response against apoptosis, which would be consistent with evidence that $\mathrm{NF} \kappa \mathrm{B}$ activation acts to block apoptosis or to give rise to a survival signal after TNF- $\alpha$ treatment (Baeuerle and Baltimore, 1996; Beg and Baltimore, 1996; Liu et al., 1996; Van Antwerp et al., 1996).

To assess whether the activity of $\mathrm{NF} \kappa \mathrm{B}$ is modulated by oligodendrocytes, we used a monoclonal antibody specific for the activated form of p65/RelA to examine the expression of $\mathrm{p} 65 /$ RelA protein in oligodendrocytes after infection with control or trkA-expressing virus. NGF treatment of $\mathrm{p} 75^{+}$oligodendrocytes resulted in an increase in nuclear localization of the RelA subunit, indicating that translocation of the p65 subunit was induced in differentiated oligodendrocyte cells (Fig. 7, top).

To verify $\mathrm{NF} \kappa \mathrm{B}$ activation by NGF, an electrophoretic mobility

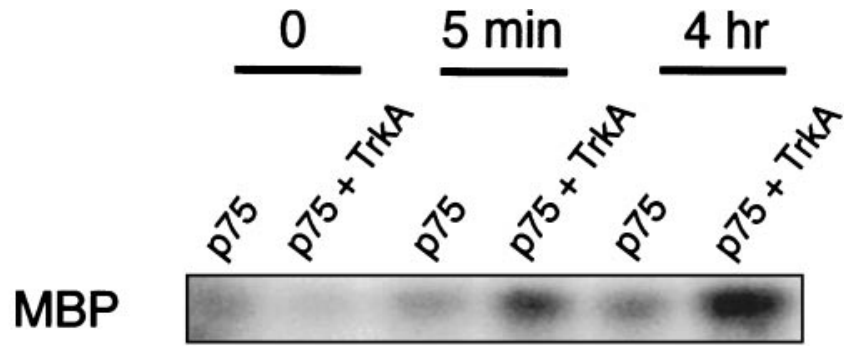

GST-jun

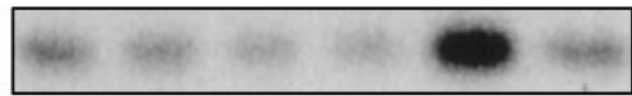

Figure 5. Activation of TrkA shifts the balance between MAP kinases and JNK. Control differentiated cultures infected with the control virus $\left(p 75^{+}\right)$and cultures infected with the TrkA virus $(p 75+\operatorname{Trk} A)$ were treated or left untreated with $100 \mathrm{ng} / \mathrm{ml} \mathrm{NGF}$ for $5 \mathrm{~min}$ or $4 \mathrm{hr}$. Lysates were prepared and subjected to immunoprecipitation/kinase assays, using MBP as a substrate for MAP kinase activity and GST-jun as a substrate for JNK activity. The experiments were repeated three times with similar results.

gel shift analysis was performed using a ${ }^{32} \mathrm{P}$-labeled oligonucleotide containing a consensus $\mathrm{NF} \kappa \mathrm{B}$ sequence. Total cellular extracts isolated under high-salt conditions from $\mathrm{p} 75^{+}$oligodendrocytes were used for these experiments. A sequence-specific complex was observed that was competed by excess unlabeled oligonucleotide. This complex was frequently observed in untreated lysates; however, the gel shift complex was increased after NGF treatment of oligodendrocytes (Fig. 7, bottom). In oligodendrocytes expressing both p75 and TrkA receptor, a similar $\mathrm{NF} \kappa \mathrm{B}$ DNA-binding activity as well as a nuclear translocation of the RelA subunit were observed (Fig. 7, bottom). These results indicate that activation of TrkA by NGF did not affect $\mathrm{NF} \kappa \mathrm{B}$ induction mediated by $\mathrm{p} 75$. Therefore, the effect of TrkA on p75 signaling is specific to the activation of the JNK pathway and not to the $\mathrm{NF} \kappa \mathrm{B}$ activities in oligodendrocytes. This result further implies that activation of $\mathrm{NF} \kappa \mathrm{B}$ in NGF signaling is not the sole determinant of a survival decision. This decision is likely to be dictated by the coordinated regulation of multiple factors, including $\mathrm{JNK}, \mathrm{NF} \kappa \mathrm{B}$, and MAP kinase. 

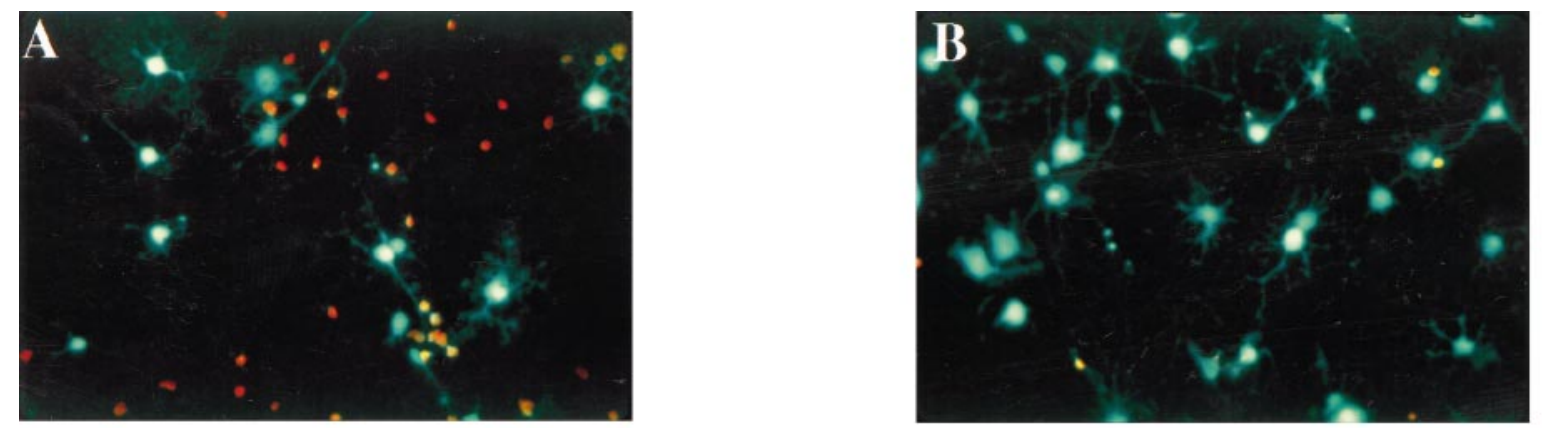

C

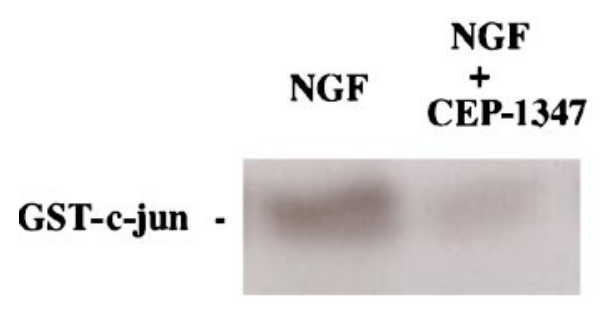

D

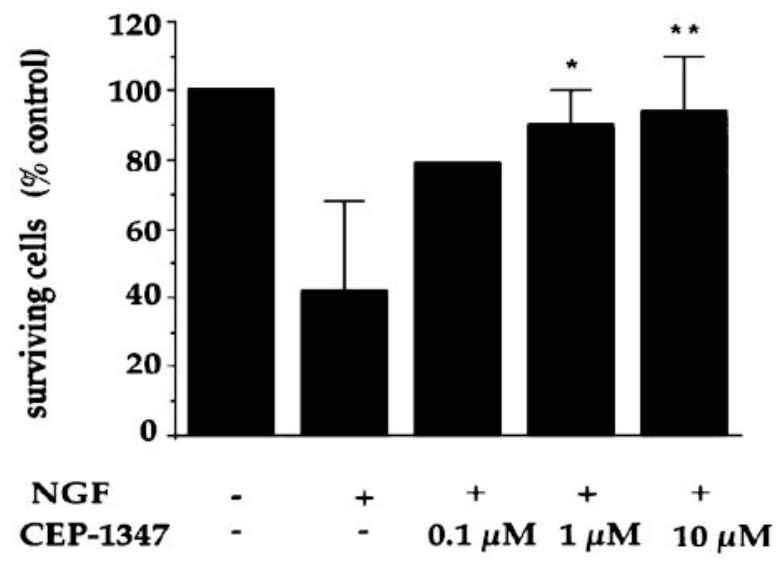

Figure 6. Inhibition of JNK activity prevents NGF-induced cell death in oligodendrocytes. Double immunofluorescence of cultures treated for 4 hr with $100 \mathrm{ng}$ of NGF $(A)$ or $100 \mathrm{ng}$ of NGF plus $1 \mu \mathrm{M}$ CEP-1347 $(B)$ and then stained live with ethidium and calcein AM. Red nuclei indicate dying cells, and green fluorescent cells reflect surviving oligodendrocytes. $C$, c-Jun kinase assay on cell lysates obtained from cultures treated with $100 \mathrm{ng} / \mathrm{ml} \mathrm{NGF}$ and $100 \mathrm{ng} / \mathrm{ml}$ NGF plus $1 \mu \mathrm{M}$ CEP-1347 for $4 \mathrm{hr}$. The experiment was performed in duplicate. $D$, Quantitation of surviving cells (number of green fluorescent cells) after 4-8 hr treatment with NGF $(100 \mathrm{ng} / \mathrm{ml})$ or NGF $(100 \mathrm{ng} / \mathrm{ml})$ plus CEP-1347 at increasing concentrations. The results represent the mean \pm SEM of the cells from 6 to 10 determinations (except for controls and $100 \mathrm{nM}$ CEP-1347 that was performed in duplicate). ${ }^{*} p=0.002 ;{ }^{* *} p=0.001$.

\section{DISCUSSION}

The present study suggests that the survival response to NGF is mediated by competitive signaling between TrkA and p75. This may take place at the level of receptor binding in which $\mathrm{p} 75$ and TrkA receptors participate in high-affinity site formation. This binding site may serve to recruit unique signaling substrates to the receptor complex. Another mechanism to account for receptor crosstalk is that phosphorylation events merge at points downstream of the ligand-receptor level to give an alternative outcome. This would imply that the two receptors may interact and collaborate functionally, as well as physically (Huber and Chao, 1995b; Wolf et al., 1995). The coexpression of trkA and p75 receptors results in selective downregulation of potential stress-induced signals by p75, such as the JNK pathway, and simultaneous upregulation of MAP kinases and the steps leading to $\mathrm{NF} \kappa \mathrm{B}$ activation. The balance between the activities of different MAP kinase subfamilies appears to play a determining role in survival decisions. These results are reminiscent of cell death induced in PC12 cells after NGF withdrawal, in which JNK activities are also activated (Xia et al., 1995; Park et al., 1996).

The results indicate there are at least two parallel and distinct p75 signaling pathways, $\mathrm{NF} \kappa \mathrm{B}$ and $\mathrm{JNK}$. Induction of $\mathrm{NF}_{\kappa} \mathrm{B}$ through p75 is unaffected by TrkA action. However, activation of TrkA by NGF leads to suppression of JNK activity. The ability of p75 to induce multiple pathways is reminiscent of other cytokine receptors, such as TNF receptors. TNF can also activate a variety of pathways including $\mathrm{NF} \kappa \mathrm{B}$ and $\mathrm{JNK}$ and promote many diverse cellular processes, such as apoptosis, antiviral activities, cell proliferation, and differentiation (Smith et al., 1994). It is likely that $\mathrm{p} 75$, as a member of the TNF receptor superfamily, can also initiate signaling pathways that are selectively modulated in different cell contexts. Recently, a death domain motif in the cytoplasmic region of $\mathrm{p} 75$ has been defined by nuclear magnetic resonance (NMR) analysis (Liepinsh et al., 1997). The death domain is a protein association motif that binds to cytoplasmic proteins with a potential to trigger interleukin- $\beta$-converting enzyme protease activity or other signal transduction pathways (Nagata, 1997). Based on the NMR analysis, the death domain of p75 is similar to the Fas receptor death domain but differs in its ability to aggregate (Liepinsh et al., 1997). Whether p75 functions in a similar manner to recruit substrates as Fas and TNF receptors to initiate apoptosis has not been determined.

Although the mechanism by which TrkA achieves selective modulation of p75 signaling remains to be determined, the find- 

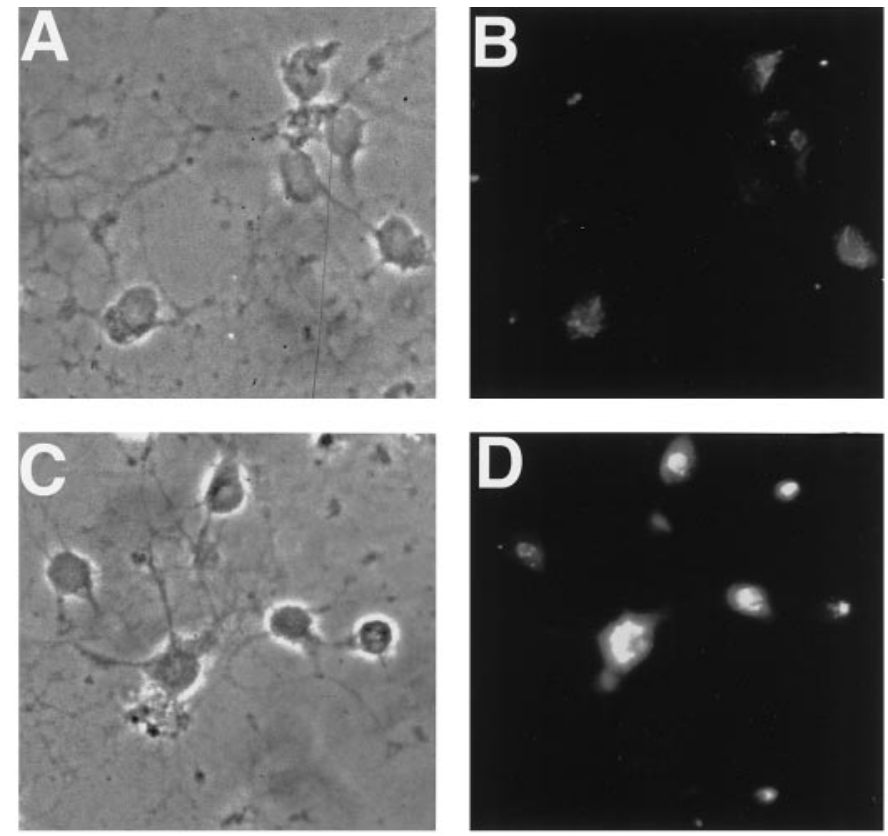

p75
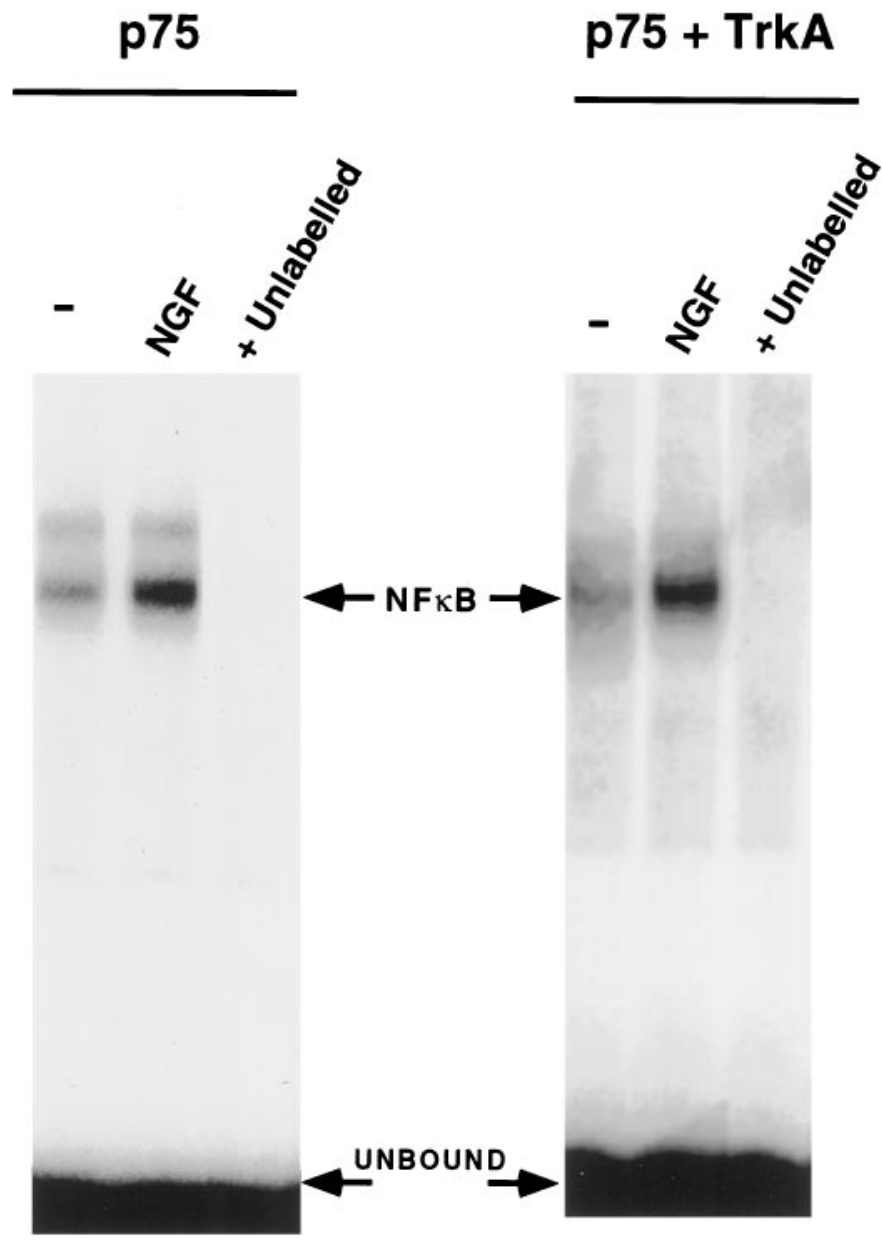

Figure 7. Top, Nuclear translocation of RelA/p65 after NGF treatment in $\mathrm{p}^{+} 5^{+}$cultures. Cultures were either left untreated $(A, B)$ or treated with $100 \mathrm{ng} / \mathrm{ml}$ NGF for $1 \mathrm{hr}(C, D)$ and then fixed in ethanol-formaldehyde. The expression of RelA/p65 was assessed by indirect immunofluorescence using monoclonal antibodies against the activated form of the RelA subunit and streptoavidin-Cy3. $A, C$, Phase-contrast photomicrographs. $B$, $D$, Immunostaining with anti-RelA antibody. Bottom, $\mathrm{NF} \kappa \mathrm{B}$ activation in

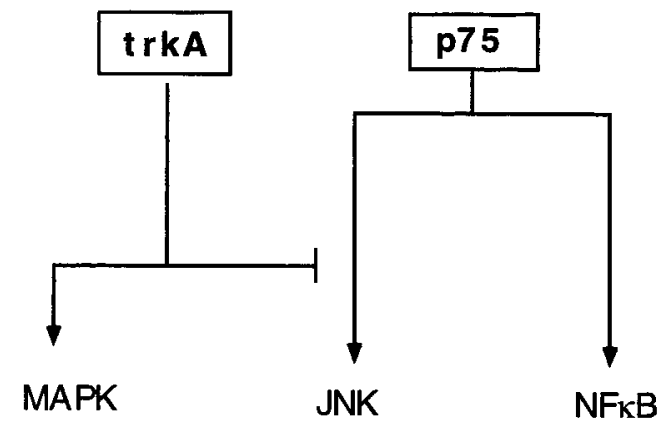

Figure 8. Model for competitive signaling between TrkA and p75 receptors in oligodendrocytes. NGF-binding to $\mathrm{p} 75$ can induce NF $\kappa \mathrm{B}$ and JNK activation, whereas TrkA activates MAP kinase phosphorylation. When the two receptors are expressed together, TrkA blocks the p75-mediated signaling leading to JNK activation. On the other hand, $\mathrm{NF} \kappa \mathrm{B}$ activation by $\mathrm{p} 75$ is left unaffected.

ing that TrkA activation selectively blocks p75-mediated death is consistent with previous data, indicating that TrkA modulates p75 signaling through sphingomyelin hydrolysis. Neurotrophins induce ceramide production in cells expressing only p75 (Dobrowsky et al., 1995), but in cells expressing both p75 and TrkA, sphingomyelin hydrolysis is not observed.

One possible explanation for this effect is the production of sphingosine-1-phosphate by TrkA (Edsall et al., 1997). Sphingosine-1-phosphate activates MAP kinases in tumor cell lines such as U937 and also inhibits JNK activity induced by TNF- $\alpha$ or ceramide. Production of sphingosine-1-phosphate through TrkA might lead to the induction of MAP kinases, whereas ceramide may activate JNK (Westwick et al., 1995; Verheij et al., 1996) but not $\mathrm{NF} \kappa \mathrm{B}$ activity. Therefore, it is plausible that activation of TrkA may lead to suppression of JNK activity but may allow other pathways, such as NF $\kappa$ B, to proceed.

Dual induction of $\mathrm{JNK}$ and $\mathrm{NF} \kappa \mathrm{B}$ activities may be explained by common upstream regulatory events, such as the activity of mitogen-activated protein kinase/ERK kinase kinase-1 (MEKK1), which suggests that a link exists between the two pathways in TNF signaling (Lee et al., 1997). Because TrkA leads to a selective suppression of $\mathrm{JNK}$ without affecting $\mathrm{NF} \kappa \mathrm{B}$, it may be reasoned that MEKK1 is not involved in $\mathrm{NF} \kappa \mathrm{B}$ activation by $\mathrm{p} 75$-mediated signaling. $\mathrm{NF} \kappa \mathrm{B}$ can be also be activated via a route independent of MEKK1 through the NFкB-inducing kinase (Malinin et al., 1997). Another related mechanism for $\mathrm{NF} \kappa \mathrm{B}$ activation by $\mathrm{p} 75$ may be in the recruitment of adaptor molecules, such as the TNF receptor-associated factors that are required for $\mathrm{NF} \kappa \mathrm{B}$ activation by TNF and interleukin 1 receptors (Rothe et al., 1995; Cao et al., 1996). Identification of interacting proteins for the p75 receptor will undoubtedly shed some light on this question.

A model can be proposed in which p75 can influence cell signaling through multiple mechanisms, some of which are suppressed by TrkA function (Fig. 8). In this model, TrkA activates the MAP kinase survival signal but suppresses the p75-mediated JNK death signal. Accordingly, without TrkA receptors, NGF may potentially activate the stress-activated JNK pathway, lead-

$\leftarrow$

oligodendrocytes. TrkA expression does not affect $\mathrm{NF} \kappa \mathrm{B}$ activation by p75. DNA binding activity of $\mathrm{NF}_{\kappa} \mathrm{B}$ in control and TrkA-expressing oligodendroglial cultures is shown. Lysates were prepared from cultures and assessed for electrophoretic gel mobility shift using a ${ }^{32} \mathrm{P}$-labeled oligonucleotide with a $\kappa$ light chain enhancer sequence. 
ing to cell death through p75. The involvement of JNK in p75mediated cell death is substantiated by the ability of the JNK pathway inhibitor CEP-1347 to block apoptosis induced by NGF. Alternatively, selective activation of p75 may influence TrkA signaling through changes in its phosphorylation state (MacPhee and Barker, 1997). The decision between neurotrophin survival or death may be determined by coordinated regulation of multiple signals through bidirectional receptor pathways.

Is expression of p75 sufficient to induce cell death by NGF? This is a pertinent question, because the majority of cells expressing p75 do not die in response to NGF. For oligodendrocytes, cell death by NGF has several requirements, of which the most important is the state of terminal differentiation. Grown in the absence of mitogens and growth factors, oligodendrocytes mature in culture and begin to express p 75 at high levels that are maximal after growth in differentiation media for $>1$ week. This is a stage when cells became most susceptible to NGF-mediated cell death. Notably, no effects on cell viability by NGF were observed in oligodendrocyte progenitor cells that expressed undetectable levels of p75. Also, introduction of p75 in progenitor cells using a p75 adenovirus vector (Yoon et al., 1996) did not result in death of these cells after NGF treatment (data not shown). An inherent difference between progenitor and mature oligodendrocytes must exist. Therefore, it is clear the mere expression of p75 receptors is not sufficient to cause death. Consistent with this conclusion is the absence of cell death in cultured Schwann cells that express very high levels of $\mathrm{p} 75$. Other death pathway proteins or a specific cell competence factor may be required to engage the cell death program after $\mathrm{p} 75$ induction.

The p75 receptor is not normally expressed by oligodendrocytes found in the optic nerve or in the CNS. However, a number of reports have documented that many glial cells express p75 after nerve lesion or injury (Raivich et al., 1991; Hutton et al., 1992; Frisen et al., 1993; Kumar et al., 1993; Junier et al., 1994; Cohen et al., 1996). Glial cells in vivo also possess the potential of expressing several other TNF receptor family members, including the Fas antigen (D’Souza et al., 1996; Dowling et al., 1996). Strikingly, p75-positive oligodendrocytes can be detected in white matter plaques from cases of multiple sclerosis (Dowling et al., 1997). Some of the $\mathrm{p} 75^{+}$oligodendrocytes found in these plaques are apoptotic, raising the possibility that the cell culture conditions used here to observe NGF-mediated oligodendrocyte cell death may mimic the inflammatory or traumatic conditions that produce reactive glial cells. Detection of high levels of p75 in Schwann cells after nerve lesion or in culture (Johnson et al., 1988; Lemke and Chao, 1988) suggests that the expression of p75 may reflect a common reaction for glial cells that is accelerated after nerve lesion or injury. The p75 receptor may be more accurately regarded as a stress receptor, similar in behavior to other TNF family members.

An important conclusion from this investigation is that survival decisions are dependent on a balance between different signaling pathways. The strength and duration of receptor signaling and how each signal intersects with other pathways may convert a survival to an apoptotic outcome. A case in point is the demonstration of apoptosis in medulloblastoma tumor cells by NGF binding to TrkA receptors (Muragaki et al., 1997). In contrast, in terminally differentiated oligodendrocytes, activation of the TrkA receptor tyrosine kinase by NGF can overcome cell death. To understand how these receptor-mediated events determine the regulation by NGF of cell viability, it will be necessary to identify the convergent steps created by competitive receptor signaling.

\section{REFERENCES}

Althaus HH, Kloppner S, Schmidt-Schultz T, Schwartz P (1992) Nerve growth factor induces proliferation and enhances fiber regeneration in oligodendrocytes isolated from adult pig brain. Neurosci Lett 135:219-223.

Baeuerle PA, Baltimore D (1996) NF- $\kappa$ B: ten years after. Cell 87:13-20.

Barbacid M (1994) The trk family of neurotrophin receptors. J Neurobiol 25:1386-1403.

Barker PA, Shooter EM (1994) Disruption of NGF binding to the lowaffinity neurotrophin receptor p75 reduces NGF binding to trkA on PC12 cells. Neuron 13:203-215.

Barrett GL, Bartlett PF (1994) The p75 receptor mediates survival or death depending on the stage of sensory neuron development. Proc Natl Acad Sci USA 91:6501-6505.

Beg AA, Baltimore D (1996) An essential role for NF- $\kappa$ B in preventing TNF- $\alpha$-induced cell death. Science 274:782-784.

Bothwell M (1996) p75 ${ }^{\mathrm{NTR}}$ : a receptor after all. Science 272:506-507.

Bredesen DE, Rabizadeh S (1997) $\mathrm{p}^{\mathrm{NTR}}$ and apoptosis: Trkdependent and Trk-independent effects. Trends Neurosci 20:287-291.

Cao Z, Xiong J, Takeuchi M, Kurama T, Goeddel DV (1996) TRAF6 is a signal transducer for interleukin-1. Nature 383:443-446.

Carter BD, Lewin GR (1997) Neurotrophins live or let die: does p75 ${ }^{\text {NTR }}$ decide? Neuron 18:187-190.

Carter BD, Kaltschmidt C, Kaltschmidt B, Offenhauser N, BohmMatthaei R, Baeuerle PA, Barde Y-A (1996) Selective activation of $\mathrm{NF}-\kappa \mathrm{B}$ by nerve growth factor through the neurotrophin receptor $\mathrm{p} 75$. Science 272:542-545.

Casaccia-Bonnefil P, Carter BD, Dobrowsky RT, Chao MV (1996) Death of oligodendrocytes mediated by the interaction of nerve growth factor with its receptor p75. Nature 383:716-719.

Chao MV (1992) Neurotrophin receptors: a window into neuronal differentiation. Neuron 9:583-593.

Cohen RI, Marmur R, Norton WT, Mehler MF, Kessler JA (1996) Nerve growth factor and neurotrophin-3 differentially regulate the proliferation and survival of developing rat brain oligodendrocytes. J Neurosci 16:6433-6442.

D’Souza SD, Bonetti B, Balasingham V, Cashman NR, Barker PA, Raine CS, Antel JP (1996) Multiple sclerosis: fas signaling in oligodendrocyte cell death. J Exp Med 184:2361-2370.

Davies A, Lee K-F, Jaenisch R (1993) p75 deficient trigeminal sensory neurons have an altered response to NGF but not to other neurotrophins. Neuron 11:1-20.

Derijard B, Hibi M, Wu I-H, Barret T, Su B, Deng T, Karin M, Davis R (1994) JNK1: a protein kinase stimulated by UV light and Ha-Ras that binds and phosphorylates the c-Jun activation domain. Cell 76:1025-1037.

Dobrowsky RT, Jenkins GM, Hannun YA (1995) Neurotrophins induce sphingomyelin hydrolysis. J Biol Chem 270:22135-22142.

Dowling P, Shang G, Raval S, Menonna J, Cook S, Husar W (1996) Involvement of the CD95 (APO-1/Fas) receptor/ligand system in multiple sclerosis brain. J Exp Med 184:1513-1518.

Dowling P, Raval S, Husar W, Casaccia-Bonnefil P, Chao M, Cook S, Blumberg B (1997) Expression of the p75 neurotrophin receptor in oligodendrocytes in multiple sclerosis brain. Neurology 48:A25.

Edsall LC, Pirianov GG, Spiegel S (1997) Involvement of sphingosine 1-phosphate in nerve growth factor-mediated neuronal survival and differentiation. J Neurosci 17:6952-6960.

Fields-Berry SC, Halliday AL, Cepko CL (1992) A recombinant retrovirus encoding alkaline phosphatase confirms clonal boundary assignment in lineage analysis of murine retina. Proc Natl Acad Sci USA 89:693-697.

Frade JM, Rodriguez-Tebar A, Barde Y-A (1996) Induction of cell death by endogenous nerve growth factor through its p75 receptor. Nature 383:166-168.

Frisen J, Verge VMK, Fried K, Risling M, Persson H, Trotter J, Hokfelt T, Lindholm D (1993) Characterization of glial trkB receptors: differential response to injury in the central and peripheral nervous systems. Proc Natl Acad Sci USA 90:4971-4975.

Greene LA, Kaplan DR (1995) Early events in neurotrophin signaling via Trk and p75 receptors. Curr Top Neurobiol 5:579-587.

Ham J, Babij C, Whitfield J, Pfarr CM, Lallemand D, Yaniv M, Rubin LL (1995) A c-Jun dominant negative mutant protects sympathetic neurons against programmed cell death. Neuron 14:927-939.

Hempstead BL, Martin-Zanca D, Kaplan DR, Parada LF, Chao MV (1991) High-affinity NGF binding requires co-expression of the trk proto-oncogene and the low-affinity NGF receptor. Nature 350:678-683. 
Hempstead BL, Rabin SJ, Kaplan L, Reid S, Parada LF, Kaplan DR (1992) Overexpression of the trk tyrosine kinase rapidly accelerates nerve growth factor-induced differentiation. Neuron 9:883-896.

Huber LJ, Chao MV (1995a) Mesenchymal and neuronal cell expression of the p75 neurotrophin receptor are distinguished during morphogenesis of transgenic animals. Dev Biol 167:227-238.

Huber LJ, Chao MV (1995b) A potential interaction of p75 and trkA NGF receptors revealed by affinity crosslinking and immunoprecipitation. J Neurosci Res 40:557-563.

Hutton LA, deVellis J, Perez-Polo JR (1992) Expression of p75 NGFR, TrkA, and TrkB mRNA in rat C6 glioma and type I astrocyte cultures. J Neurosci Res 32:375-383.

Johnson EM, Taniuchi M, DiStefano PS (1988) Expression and possible function of NGF receptors on Schwann cells. Trends Neurosci 11:299-304.

Junier MP, Suzuki F, Onteniente B, Peschanski M (1994) Targetdeprived CNS neurons express the NGF gene while reactive glia around their axonal terminals contain low and high affinity NGF receptors. Mol Brain Res 24:247-260.

Kaneko M, Saito Y, Saito H, Matsumoto Y, Matsuda Y, Vaught JL, Dionne CA, Angeles TS, Glicksman MA, Neff NT, Rotella DP, Kauer JC, Mallamo JP, Hudkins RL, Murakata C (1997) Neurotrophic 3,9bis[(alkylthio)methyl]- and -bis(alkoxymethyl)-K-252a derivatives. J Med Chem 40:1863-1869.

Kaplan DR, Stephens RM (1994) Neurotrophin signal transduction by the trk receptor. J Neurobiol 25:1404-1417.

Kumar S, Pena LA, de Vellis J (1993) CNS glial cells express neurotrophin receptors whose levels are regulated by NGF. Mol Brain Res 17:163-168.

Lee FS, Hagler J, Chen ZJ, Maniatis T (1997) Activation of the $\mathrm{I} \kappa \mathrm{B} \alpha$ kinase complex by MEKK1, a kinase of the JNK pathway. Cell 88:213-222.

Lee K-F, Davies A, Jaenisch R (1994) p75-deficient embryonic dorsal root sensory and neonatal sympathetic neurons display a decreased sensitivity to NGF. Development 120:1027-1033.

Lemke G, Chao MV (1988) Axons regulate Schwann cell expression of major myelin and NGF receptor genes. Development 102:499-504.

Liepinsh E, Ilag LL, Otting G, Ibanez CF (1997) NMR structure of the death domain of the p75 neurotrophin receptor. EMBO J 16:4999-5005.

Liu Z-G, Hsu H, Goeddel DV, Karin M (1996) Dissection of TNF receptor 1 effector functions: JNK activation is not linked to apoptosis while NF- $\kappa$ B activation prevents cell death. Cell 87:565-576.

MacPhee IJ, Barker PA (1997) Brain-derived neurotrophic factor binding to the p75 neurotrophic receptor reduces TrkA signaling while increasing serine phosphorylation in the TrkA intracellular domain. J Biol Chem 272:23547-23551.

Mahadeo D, Kaplan L, Chao MV, Hempstead BL (1994) High affinity nerve growth factor binding displays a faster rate of association than p140(trk) binding: implications for multisubunit polypeptide receptors. J Biol Chem 269:6884-6891.

Majdan M, Lachance C, Gloster A, Aloyz R, Zeindler C, Bamji S, Bhakar A, Belliveau D, Fawcett J, Miller FD, Barker PA (1997) Transgenic mice expressing the intracellular domain of the p75 neurotrophin receptor undergo neuronal apoptosis. J Neurosci 17:6988-6998.

Malinin NL, Boldin MP, Kovalenko AV, Wallach D (1997) MAP3Krelated kinase involved in NF- $\kappa$ B induction by TNF, CD95 and IL-1. Nature 385:540-544.

Maroney AC, Glicksman MA, Basma AN, Walton KM, Knight E, Murphy CA, Bartlett BA, Finn JP, Angeles T, Matsuda Y, Neff NT, Dionne CA (1997) Motoneuron apoptosis is blocked by CEP-1347, a novel inhibitor of the JNK signaling pathway. J Neurosci 18:104-111.

Martin-Zanca D, Oskam R, Mitra G, Copeland T, Barbacid M (1989) Molecular and biochemical characterization of the human trk protooncogene. Mol Cell Biol 9:24-33.

McCarthy KD, de Vellis J (1980) Preparation of separate astroglial and oligodendroglial cell cultures from rat cerebral tissue. J Cell Biol 85:890-902.

McKinnon RD, Matsui T, Dubois-Dalcq M, Aaronson SA (1990) FGF modulates the PDGF-driven pathway of oligodendrocyte development. Neuron 5:603-614.

Muragaki Y, Chou TT, Kaplan DR, Trojanowski J, Lee V-M (1997)
Nerve growth factor induces apoptosis in human medulloblastoma cell lines that express trkA receptors. J Neurosci 17:530-542.

Nagata S (1997) Apoptosis from death factor. Cell 85:355-365.

O'Niell LAJ, Kaltschmidt C (1997) NF- $\kappa$ B: a crucial transcription factor for glial and neuronal cell function. Trends Neurosci 20:252-258.

Park D, Stefanis L, Yan C, Farinelli S, Greene L (1996) Ordering the cell death pathway: differential effects of $\mathrm{Bcl} 2$, an interleukin-1converting enzyme family protease inhibitor, and other survival agents on JNK activation in serum/nerve growth-deprived PC12 cells. J Biol Chem 271:21898-21905.

Rabizadeh S, Oh J, Zhong LT, Yang J, Bitler CM, Butcher LL, Bredesen DE (1993) Induction of apoptosis by the low-affinity NGF receptor. Science 261:345-348.

Raff MC, Lillien LE, Richardson WD, Burne JF, Noble MD (1988) Platelet-derived growth factor from astrocytes drives the clock that times oligodendrocyte development in culture. Nature 333:562-565.

Raivich G, Hellweg R, Kreutzberg GW (1991) NGF receptor-mediated reduction in axonal NGF uptake and retrograde transport following sciatic nerve injury and during regeneration. Neuron 7:151-164.

Rothe M, Sarma V, Dixit VM, Goeddel DV (1995) TRAF2-mediated activation of NF- $\kappa \mathrm{B}$ by TNF receptor 2 and CD40. Science 269:1424-1427.

Smith CA, Farrah T, Goodwin RG (1994) The TNF receptor superfamily of cellular and viral proteins: activation, costimulation and death. Cell 76:959-962.

Teng KK, Landers H, Fajardo JE, Hanafusa H, Hempstead BL, Birge RB (1995) v-Crk modulation of growth factor-induced PC12 cell differentiation involves the Src homology 2 domain of v-crk and sustained activation of the ras/mitogen activated protein kinase pathway. J Biol Chem 270:20677-20685.

Van Antwerp DJ, Martin SJ, Kafri T, Green DR, Verma IM (1996) Suppression of TNF-alpha-induced apoptosis by NF-kappaB. Science 274:787-789.

Van der Zee CEEM, Ross GM, Riopelle RJ, Hagg T (1996) Survival of cholinergic forebrain neurons in developing $\mathrm{p} 75^{\mathrm{NGFR}_{-}}$-deficient mice. Science 274:1729-1732.

Verdi JM, Birren SJ, Ibanez CF, Persson H, Kaplan DR, Benedetti M, Chao MV, Anderson DJ (1994) p75(LNGFR) regulates trk signal transduction and NGF-induced neuronal differentiation in MAH cells. Neuron 12:733-745.

Verheij M, Bose R, Lin X-H, Yao B, Grant S, Birrer MJ, Szabo E, Zon LI, Kyriakis JM, Haimovitz-Friedman A, Fuks Z, Kolesnick RN (1996) Requirement for ceramide-initiated SAPK/JNK signalling in stress-induced apoptosis. Nature 380:75-79.

Westwick JK, Bielawska AE, Dbaibo G, Hannun YA, Brenner DA (1995) Ceramide activates stress-activated protein kinases. J Biol Chem 270:22689-22692.

Wolf DE, McKinnon CA, Daou M-C, Stephens RM, Kaplan DR, Ross AH (1995) Interaction with trkA immobilizes gp75 in the high affinity nerve growth factor receptor complex. J Biol Chem 270:2133-2138.

Wyatt S, Davies AM (1993) Regulation of expression of mRNAs encoding the nerve growth factor receptors p75 and trkA mRNA in developing sensory neurons. Development 119:635-647.

Wyatt S, Davies AM (1995) Regulation of nerve growth factor gene expression in sympathetic neurons during development. J Cell Biol 130:1435-1446.

Xia Z, Dickens M, Raingeaud J, Davis RJ, Greenberg ME (1995) Opposing effects of ERK and JNK-p38 MAP kinases on apoptosis induced by neurotrophic factor withdrawal. Science 270:1326-1331.

Yao R, Cooper GM (1995) Requirement for phosphatidylinositol-3 kinase in the prevention of apoptosis by nerve growth factor. Science 267:2003-2006.

Yeo TT, Chua-Couzens J, Butcher LL, Bredesen DE, Cooper JD (1997) Absence of $\mathrm{p} 75^{\mathrm{NTR}}$ causes increased basal forebrain cholinergic neuron size, choline acetyltransferase activity, and target innervation. J Neurosci 17:7594-7605.

Yoon SO, Lois C, Alvirez M, Alvarez-Buylla A, Falck-Pedersen E, Chao MV (1996) Adenovirus-mediated gene delivery into neuronal precursors of the adult mouse brain. Proc Natl Acad Sci USA 93:11974-11979. 